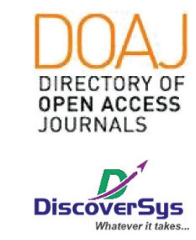

Published by DiscoverSys

\title{
Uji korelasi leukosit esterase dan nitrit dengan kultur urin pada infeksi saluran kemih
}

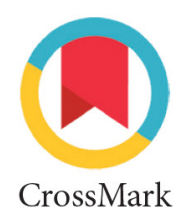

\author{
Ursula Nauli Malau ${ }^{1 *}$, Purwanto Adipireno ${ }^{2}$
}

\section{ABSTRACT}

Background: Urinary tract infection (UTI) is a condition where the urinary tract is infected by pathogens, causing microorganisms in urine. The gold standard examination for UTI is urine culture. Urine culture has some weaknessess. It takes around two days to get result and requires quite expensive cost. Leukocyte esterase and nitrite are relatively inexpensive, less-time consuming and easy to do laboratory tests that can detect UTI.

Aim: To explore the correlation of leukocyte esterase and nitrite with urine culture in UTI patients.

Methods: A cross sectional study of 42 UTI adult patients which treated at Dr. Kariadi hospital Semarang in September until October
2018. Combur dipstick using colorimetry method and urine culture using convensional method. Correlation test analyze using contingency coefficient.

Results: The correlation analysis showed there was a positive correlation between urine esterase leukocytes with urine culture ( $p$ $=0.044$ and $r=0.152$ ) and there was no correlation between urine nitrite with urine culture $(p=0.272)$,

Conclusion: There was a correlation between urine leukocyte esterase and urine culture and there was no correlation between the urine nitrite to urine culture. However further researches are needed to analyze factors that affecting the UTI diagnostic.

Keywords: urinary tract infection, leukocyte esterase, nitrite, urine culture

Cite This Article: Malau, U.N., Adipireno, P. 2019. Uji korelasi leukosit esterase dan nitrit dengan kultur urin pada infeksi saluran kemih. Intisari Sains Medis 10 (1): 184-187. D0I: 10.1556/ism.v10i1.343

\section{ABSTRAK}

Pendahuluan: Infeksi saluran kemih (ISK) merupakan keadaan dimana saluran kemih terinfeksi oleh mikroorganisme patogen sehingga menyebabkan terdapat mikroorganisme pada urin. Pemeriksaan baku emas ISK adalah kultur urin untuk melihat adanya mikroorganisme patogen penyebab ISK. Kelemahan kultur urin diantaranya memerlukan waktu sekitar dua hari untuk mendapatkan hasil serta biaya yang cukup mahal. Pemeriksaan laboratorium lain yang dapat memberikan hasil secara cepat, relatif murah dan mudah dilakukan untuk mendeteksi ISK adalah leukosit esterase dan nitrit.

Tujuan: Penelitian bertujuan untuk menganalisis hubungan antara hasil pemeriksaan leukosit esterase dan nitrit dengan pemeriksaan kultur urin.

Metode: Penelitian potong-lintang pada 42 sampel pasien dewasa yang menderita ISK di RSUP Dr. Kariadi Semarang selama September sampai Oktober 2018. Metode pemeriksaan disptick Combur adalah kolorimetri dan kultur menggunakan metode konvensional. Uji korelasi menggunakan contingency coefficient test.

Hasil: Terdapat hubungan positif lemah antara leukosit esterase urin dengan kultur urine $(p=0,044$ dan $r=0,152)$ serta tidak terdapat hubungan bermakna dari nitrit urin dengan kultur urin ( $p$ $=0,272$ ).

Simpulan: Terdapat hubungan antara leukosit esterase urin dengan kultur urin. Tidak terdapat hubungan antara nitrit urin terhadap kultur urin. Penelitian lebih lanjut diperlukan untuk menganalisis faktor-faktor yang berpengaruh dalam mendiagnosis ISK.

Kata Kunci: infeksi saluran kemih, leukosit esterase, nitrit, kultur urin

Cite Pasal ini: Malau, U.N., Adipireno, P. 2019. Uji korelasi leukosit esterase dan nitrit dengan kultur urin pada infeksi saluran kemih. Intisari Sains Medis 10 (1): 184-187. D0I: 10.1556/ism.v10i1.343

*Korespondensi: Ursula Nauli Malau; PPDS-1 Patologi Klinik, Fakultas Kedokteran Universitas Diponegoro/RSUP Dr. Kariadi Semarang sigenlaladut88@gmail.com

Diterima: 01-11-2018

Disetujui: 03-26-2019

Diterbitkan: 04-01-2019

\section{PENDAHULUAN}

Menurut World Health Organization (WHO), infeksi saluran kemih (ISK) adalah penyakit infeksi kedua tersering setelah infeksi saluran pernafasan dan sebanyak 8,3 juta kasus dilaporkan per tahun. Infeksi ini lebih sering dijumpai pada perempuan daripada laki-laki. Prevalensi ISK pada usia kurang dari 40 tahun sebesar 3,2\% sedangkan prevalensi ISK pada usia diatas 65 tahun sebesar 20\%. Menurut perkiraan Departemen Kesehatan Republik Indonesia, jumlah penderita ISK di Indonesia adalah 90-100 kasus per 100.000 penduduk pertahun atau sekitar 180.000 kasus baru 
pertahun. ${ }^{1}$

ISK merupakan keadaan dimana saluran kemih terinfeksi oleh mikroorganisme patogen sehingga menyebabkan adanya mikroorganisme pada urin. Untuk menentukan benar atau tidaknya pasien menderita ISK dibutuhkan diagnosis yang adekuat. Salah satu cara mendiagnosis ISK dengan pemeriksaan sampel urin.

Pemeriksaan baku emas ISK adalah kultur urin untuk melihat adanya mikroorganisme patogen penyebab ISK dan jumlah kolonisasi bakteri. Kelemahan kultur urin diantaranya memerlukan waktu sekitar dua hari untuk mendapatkan hasil dan membutuhkan biaya yang cukup mahal. Pemeriksaan kultur urin dapat memberikan hasil negatif palsu akibat penggunaan antibiotik sebelumnya. Pelayanan pemeriksaan kultur urin juga tidak terdapat di semua laboratorium. Hal-hal tersebut dapat menyebabkan pengobatan tertunda sehingga dibutuhkan baku emas diagnostik baru yang dapat menggantikan kultur urin. Penegakkan diagnosis ISK harus dilakukan secara adekuat dan cepat agar dapat dilakukan penanganan secepat mungkin sehingga terhindar dari komplikasi. . $^{2,3,4}$

Salah satu alat diagnostik untuk menegakkan diagnosis ISK adalah tes dipstick urin yang mampu mendeteksi leukosit esterase sebagai indikator piuria dan nitrit sebagai indikator bakteriuria. Leukosit esterase pada tes dipstick urin dapat mendeteksi enzim esterase yang dihasilkan oleh leukosit di dalam urin. Perubahan nitrat menjadi nitrit terjadi

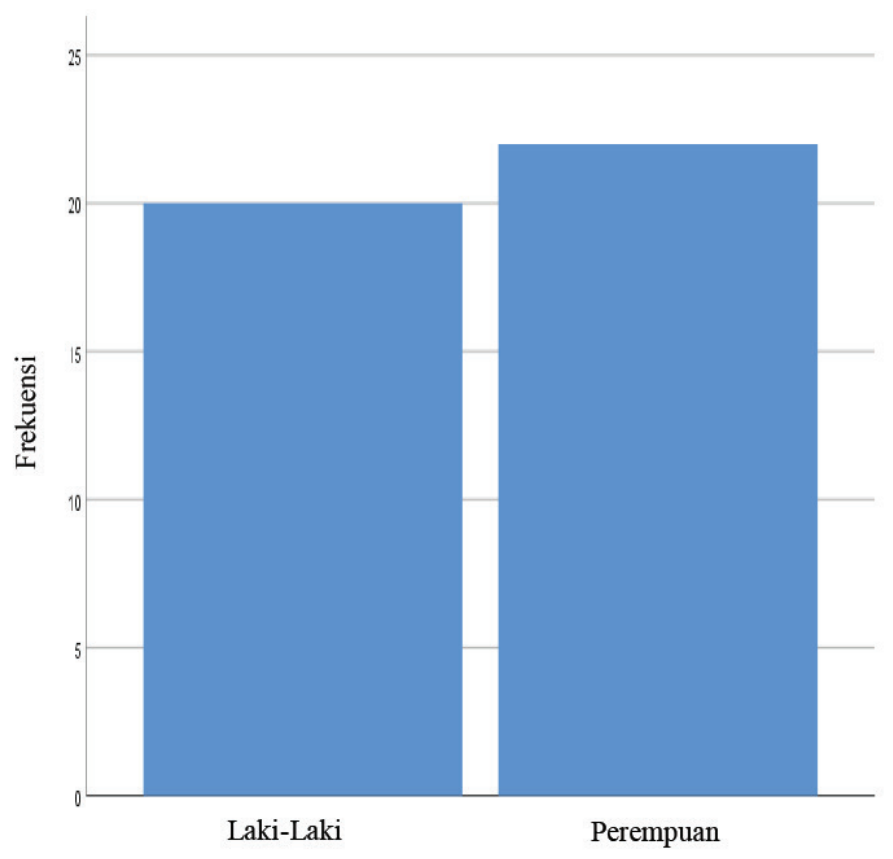

Jenis kelamin akibat adanya bakteri yang menghasilkan enzim nitrat reduktase. Bakteri yang dapat memproduksi enzim tersebut adalah bakteri gram negatif seperti Escherichia, Enterobacter, Citrobacter, Proteus, Kleibsiella dan Pseudomonas.

Tes leukosit esterase dan nitrit pada urin merupakan pemeriksaan yang dapat memberikan hasil secara cepat, relatif murah dan mudah dilakukan. Tes ini juga dapat menjadi metode screening untuk mendiagnosis ISK. ${ }^{5,6}$ Oleh karena itu penulis tertarik untuk meneliti lebih lanjut hubungan antara leukosit esterase dan nitrit dengan kultur urin sebagai baku emas diagnosis ISK. Penelitian ini bertujuan untuk menganalisis hubungan antara leukosit esterase dan nitrit dengan kultur urine pada pasien ISK.

\section{METODE PENELITIAN}

Penelitian ini merupakan penelitian potonglintang (cross sectional) yang dilakukan selama bulan September sampai Oktober 2018 di RSUP Dr. Kariadi Semarang. Penelitian ini menginklusi pasien dewasa RSUP Dr. Kariadi dengan diagnosis ISK, sedangkan kriteria eksklusi adalah hasil kultur urin yang terkontaminasi, pasien dengan riwayat pemakaian kateter urin serta pasien dengan riwayat terapi vitamin C. Penelitian melibatkan 42 pasien yang memenuhi kriteria inklusi. Data penelitian diambil dari rekam medis pasien. Metode pemeriksaan dipstick Combur adalah kolorimetri dan kultur menggunakan metode konvensional. Ethical clearance No.557/EC/FK-RSDK/VIII/2018 diperoleh dari komite etik penelitian kedokteran dan kesehatan, Fakultas Kedokteran Universitas Diponegoro Semarang. ${ }^{7}$ Analisis data yang diperoleh menggunakan komputer. Uji korelasi data menggunakan contingency coefficient (pearson's coefficient) test. Analisis statistik diolah menggunakan program komputer SPSS versi 19.0. Nilai $p$ bermakna apabila $<0,05$ dan interval kepercayaan $95 \%{ }^{8}$

\section{HASIL}

Penelitian dilakukan terhadap 42 sampel subjek penelitian yang memenuhi kriteria inklusi dan eksklusi. Berdasarkan Gambar 1 dapat diketahui $20(47,6 \%)$ subjek berjenis kelamin laki-laki dan 22 $(52,4 \%)$ subjek berjenis kelamin perempuan.

Gambar 2 menunjukkan distribusi usia subjek penelitian. Subjek penelitian dengan usia 20-30 tahun berjumlah $9(21,4 \%)$ subjek, usia 31-40 tahun berjumlah $10(23,9 \%)$ subjek, usia 41-50 tahun berjumlah $9(21,4 \%)$ subjek dan usia 51-60 tahun berjumlah $14(33,3 \%)$ subjek.

Gambar 1 Distribusi Jenis Kelamin Subjek Penelitian 


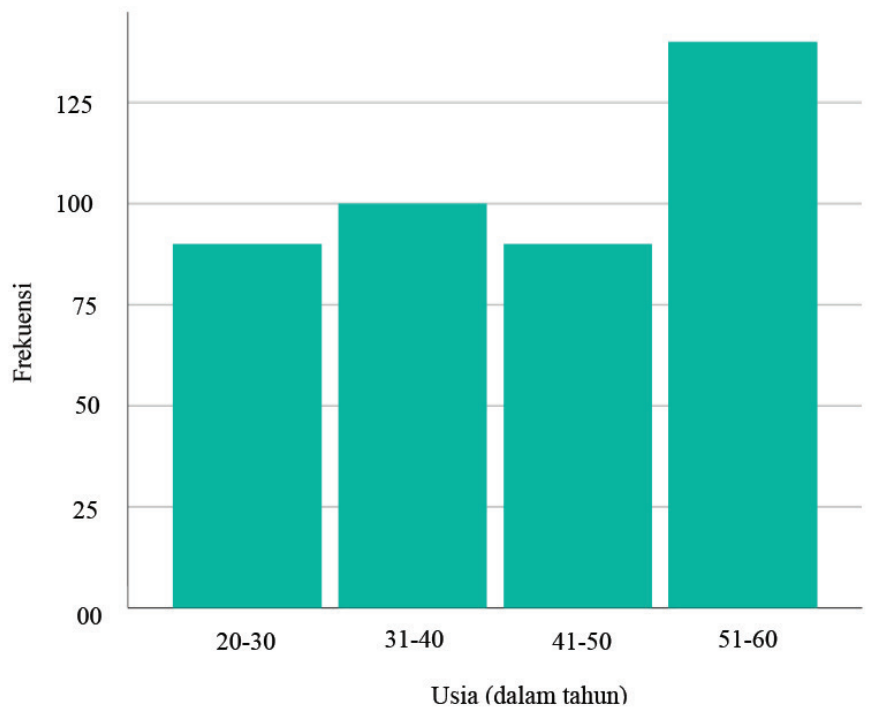

Gambar 2 Distribusi usia subjek penelitian

Tabel 1 Hasil pemeriksaan kultur urin, leukosit esterase urin dan nitrit urin

\begin{tabular}{ccc}
\hline Pemeriksaan & $\begin{array}{c}\text { Positif } \\
\mathbf{N}(\%)\end{array}$ & $\begin{array}{c}\text { Negatif } \\
\mathbf{N}(\%)\end{array}$ \\
\hline Kultur urin & $35(83,33 \%)$ & $7(16,67 \%)$ \\
Leukosit esterase urin & $26(61,90 \%)$ & $16(38,10)$ \\
Nitrit urin & $12(28,57 \%)$ & $30(71,43 \%)$ \\
\hline
\end{tabular}

Tabel 2 Bakteri penyebab ISK berdasarkan kultur urin

\begin{tabular}{lll}
\hline Jenis bakteri & N & Persentase (\%) \\
\hline Eschericia coli & 8 & 22,86 \\
Klebsiela pneumonia & 7 & 20 \\
Staphylococcus haemolyticus & 6 & 17,15 \\
Pseudomonas aeruginosa & 4 & 11,43 \\
Acinobacter lowfii & 4 & 11,43 \\
Enterococcus faecalis & 4 & 11,43 \\
Acinetobacter baumanii & 1 & 2,85 \\
Enterococcus faecalis & 1 & 2,85 \\
\hline
\end{tabular}

Tabel 1 menunjukkan jumlah sampel urin yang dikultur untuk melihat adanya pertumbuhan bakteri. Sebanyak 42 sampel urin memiliki nilai pertumbuhan bakteri yang berbeda. Total 35 sampel menunjukkan hasil pertumbuhan bakteri $\geq 100.000$, nilai ini menandakan positif adanya ISK. Sedangkan 7 sampel urin lainnya yang dikultur menunjukkan hasil negatif.

Hasil pemeriksaan leukosit esterase urin ditampilkan pada Tabel 1 Pada pemeriksaan patch tes terjadi perubahan warna menjadi warna ungu merupakan indikasi adanya leukosit esterase dalam urin. Terdapat 26 sampel urin yang memiliki nilai positif dan 16 sampel sampel urin yang memberikan hasil negatif.

Hasil pemeriksaan nitrit urin juga ditampilkan pada Tabel 1 Perubahan warna pada patch tes menjadi merah muda sampai merah, bahkan warna merah muda sedikitpun adalah indikasi adanya bakteri dalam urin yang mampu mengubah nitrat menjadi nitrit. Pada pemeriksaan nitrit urin yang dilakukan, ditemukan 12 sampel urin yang memberikan hasil positif dan 30 sampel sampel urin yang memberikan hasil negatif.

Berdasarkan Tabel 2 diketahui bahwa dari 35 sampel kultur urin positif, terdapat tiga jenis bakteri terbanyak penyebab ISK yaitu Eschericia coli sebanyak 8 (22,86\%), Klebsiella pneumoniae sebanyak 7 (20\%), dan Staphylococcus haemolyticus sebanyak $6(17,15 \%)$.

Penelitian ini menunjukkan bahwa terdapat hubungan positif lemah antara leukosit esterase urin dengan kultur urin dengan $\mathrm{p}=0,044$ dan $\mathrm{r}=$ 0,152 (Gambar 3).

\section{PEMBAHASAN}

Strip reagen mendeteksi leukosit esterase yang ditemukan dalam granulosit (neutrofil, eosinofil, dan basofil). Adanya esterase digunakan sebagai petunjuk adanya neutrofil di dalam urin meskipun pada pemeriksaan mikroskopis seringkali tidak ditemukan leukosit. Peningkatan jumlah neutrofil dalam urin dapat menjadi petunjuk adanya ISK. Hasil positif leukosit esterase memiliki hubungan yang bermakna terhadap jumlah neutrofil, baik dalam keadaan utuh maupun lisis. Jadi leukosit esterase dapat menggambarkan adanya piuria. Keuntungan dari pemeriksaan ini adalah kemampuannya untuk mendeteksi leukosit baik intak maupun yang sudah lisis. ${ }^{5,6}$

Tidak terdapat hubungan antara nitrit urin dengan kultur urin dengan $p=0,272$. Hal ini dapat disebabkan karena tidak semua bakteri dapat mengubah nitrat menjadi nitrit. Bakteri patogen dalam saluran kemih seperti Escherichia colli, Enterobacter, Citrobacter, Klebsiella dan Proteus mengandung enzim nitrat reduktase yang dapat mereduksi nitrat menjadi nitrit. Pemeriksaan nitrit urin dapat memberikan hasil positif jika terdapat bakteri urin dalam jumlah signifikan yang dapat mengubah nitrat menjadi nitrit., ${ }^{9,10}$

Penelitian ini memiliki keterbatasan yaitu tidak memperhatikan pola pemberian antibiotik pada pasien yang menjadi subjek penelitian. Pola pemberian antibiotik yang berlebihan sebelum diagnosis infeksi oleh bakteri ditegakkan akan menyebabkan hasil negatif palsu pada hasil 


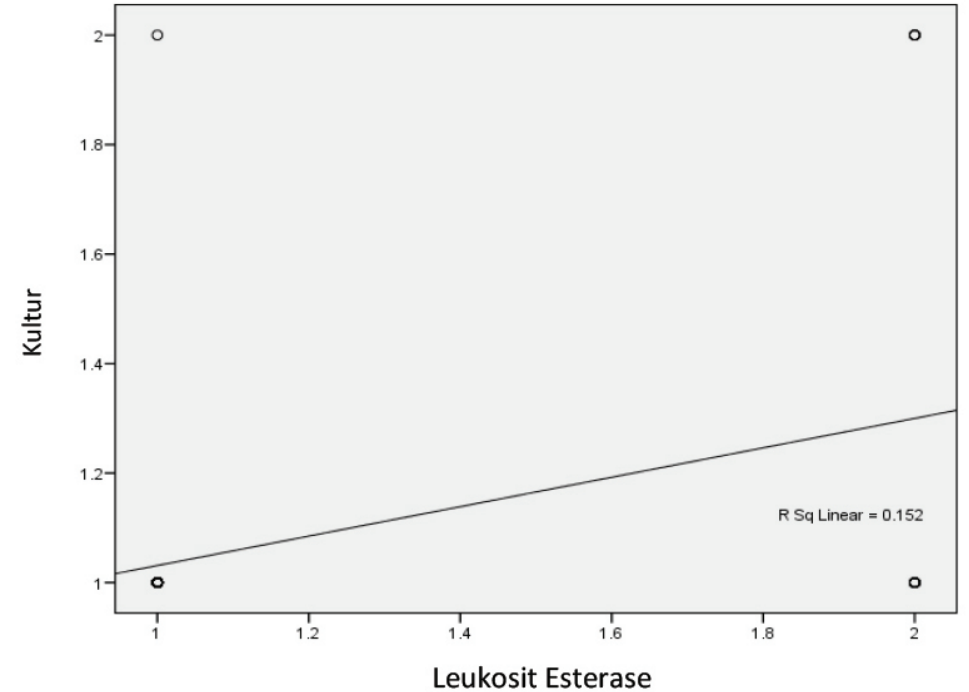

Gambar 3 Grafik hubungan antara leukosit esterase urin dan kultur urin masing media kultur urin memiliki manfaat yang berbeda untuk mendeteksi mikroorganisme penyebab ISK. Sebaiknya media kultur urin dipilih berdasarkan kecurigaan terhadap mikroorganisme patogen penyebab ISK pada subjek penelitian.

\section{DAFTAR PUSTAKA}

1. Darsono pv, mahdiyah p, sari m. Gambaran karakteristik ibu hamil yang mengalami infeksi saluran kemih di wilayah kerja puskesmas pekauman banjarmasin. Dinamika kesehatan. 2016;1:162-70.

2. Triasta t, setiabudi d, rachmadi d. Faktor risiko kecurigaan infeksi saluran kemih pada anak laki-laki usia sekolah dasar. Sari pediatri. 2016;18(2):137-41.

3. Minardi d, d'anzeo g, cantoro d, conti a, muzzonigro g. Urinary tract infections in women: etiology and treatment options. International journal of general medicine. 2011;4:333-43.

4. Susilo fcd. Uji diagnostik leukosituria dan bakteriuria mikroskopis langsung sampel urine untuk mendeteksi infeksi saluran kemih. Jurnal media medika muda. 2013

5. Departement of epidemiology university of michigan school of public health. Urinary tract infection syndromes - occurrence, reccurrence, bacteriology, risk factors, and disease burden. 2014:1-13.

diagnosis. Keterbatasan lainnya yaitu adanya mikroorganisme patogen yang tidak tumbuh pada biakan kultur urin. Hal ini dapat menyebabkan bias untuk menentukan mikroorganisme penyebab ISK. ${ }^{11}$

\section{SIMPULAN}

Pada penelitian ini didapatkan hubungan positif lemah antara leukosit esterase urin dengan kultur urin dan tidak terdapat hubungan bermakna antara nitrit urin dengan kultur urin.

\section{SARAN}

Penelitian lebih lanjut diperlukan untuk menganalisis faktor-faktor yang berpengaruh pada diagnostik ISK, diantaranya waktu pemberian antibiotik dengan pengumpulan sampel urin untuk pemeriksaan nitrit, leukosit esterase dan kultur urin. Sebaiknya sampel urin diambil sebelum pemberian antibiotik untuk menghindari hasil negatif palsu. Selain itu, pemilihan jenis media kultur urin merupakan salah satu faktor yang dapat mempengaruhi hasil penelitian karena masing-
6. Semeniuk $\mathrm{h}$ and church d. Evaluation of the leukocyte esterase and nitrite urine dipstick screening tests for detection of bacteriuria in women with suspected uncomplicated urinary tract infections. Journal of clinical microbiology. 1999;37(9):3051-2.

7. Arditta d dan kautsar ap. Penggunaan dipstick sebagai alat diagnosis infeksi saluran kemih pada kondisi tertentu. Farmaka. 2016;14(1):1-7.

8. Sastroasmoro s, ismael s. Dasar-dasar metodologi penelitian klinis. Jakarta, edisi 4. 2014:220-242

9. Riswanto, rizki m. Pemeriksaan kimia urine. Pustaka rasmedik. Edisi i 2015:51-117

10. Indranila ks. Standardisasi urinalisis dan pelaporannya, dalam seminar dan lokakarya update in urinalysis diagnostic. 2016:31-34.

11. García-coca marta, gadea ignacio and estbean jaime. Relationship between conventional culture and flowcytometry for the diagnosis of urinary tract infection. Journal of microbiological methods. 2017;137:14-18.

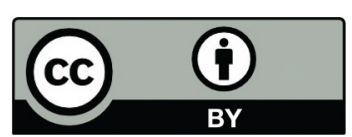

This work is licensed under a Creative Commons Attribution 